\title{
AN ECONOMIC ANALYSIS OF THE RELATIONSHIP BETWEEN ECONOMIC GROWTH AND THE ENVIRONMENT: IN IRAQ FOR THE PERIOD 2000-2017
}

\author{
* Ali S. Shukr \\ Lecturer \\ Basim H. Hameed \\ Assistant Prof.
}

Agricultural Economics Department / College of Agricultural Engineering Sciences / University of Baghdad

\section{ABSTRACT}

\author{
ali.salah.1983.economy@gmail.com
}

dr_basimbadri@yahoo.com

The research aims to study the most important factors affecting carbon dioxide emissions Co2, through a model. Explanatory variables were used in the model, which are the average per capita gross domestic product (GDP), the square per capita gross domestic product (GDPSQ), per capita energy consumption (CONS), and the POP population for the period 2000-2017 via using double logarithmic formula which is more suitable for economic, statistical and econometric logic in this type of studies, the results of the research showed that all the explanatory variables were statistically significant at the level of $1 \%$ and that the model was significant as a whole according to the statistic $F$ and the value of $R^{2}=0.99$. Economically, we find that the parameter of the average per capita GDP was 0.46 and it came with a positive signal consistent with the methodology of the Environmental Curve Kuznets ECK, the parameter of per capita energy consumption was 0.04, and it came with a negative sign that contradicts the Kuznets methodology, the reason may belong to the conditions that affected the country after 2003. The research recommended to go to investing in renewable energy, because it is environmentally friendly, such as sun energy, and to reduce the size of the gas in the sectors emitting to it, such as the transport sector, factories, the extraction sector, and manufacturing industries, in order to preserve the integrity of the environment and the plant and animal wealth it contains ,to a better environment in Iraq.

Key words: environmental economics, energy consumption, sustainable development.

* Part of Ph.D dissertation for the $1^{\text {st }}$ author

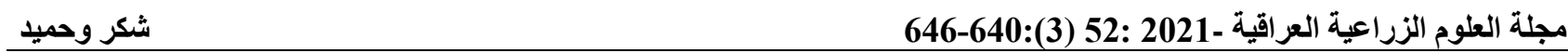

تحليل اقتصادي للعلاقة بين النمو الاقتصادي والبيئة اختبار منحنى كوزنتس البيئي في العرلق للمدة 2000-2017

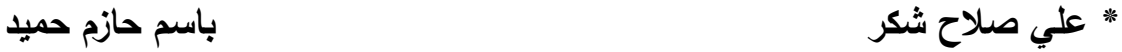

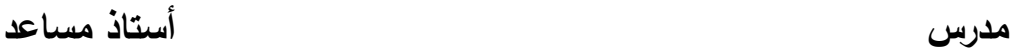

$$
\begin{aligned}
& \text { قسم الاقتصاد الزراعي / كلية علوم الهندسة الزراعية/جامعة بغداد }
\end{aligned}
$$

يهدف البحث إلى دراسة أهم العوامل المؤثرة على انبعاثات غاز ثاني اوكسيد الكاريون Co2 ، من خلال أنموذج واستخدمت المتغيرات التوضيحية في

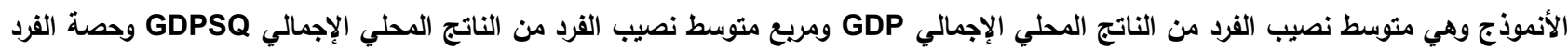
من استهلاك الطاقة مSONS وعدد السكان POP للمدة 2000-2017 والصيغة اللوغارتمية المزدوجة هي أكثر ملائمة للمنطق الاقتصادي

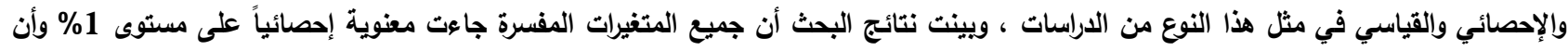
الأنموذج معنوي ككل حسب إحصائية F ويلغت قيمة م⿸ أما من الناحية الاقتصادية نجد أن معلمة متوسط نصيب الفرد من الناتج المحلي الإجمالي بلغت 0.46 وجاعت بإشارة موجبة متفقة مع منهجية منحنى كوزنتس البيئي عist متوسط نصيب الفرد من الناتج المحلي الإجمالي قد بلغت 0.036 وجاءت بإشارة سالبة متفقة أيضاً مع منهجية منحنى كوزنتس الذي أفترض الإشارة السالبة ، أما معلمة حصة الفرد من استهلاك الطاقة بلفت 0404 وجاءت بإبشارة سالبة مخالفة لمنهجية كوزنتس ويعود السبب إلى الظروف الاقتصادية التي ألمت بالبلد بعد عام 2003 ، وتخلص الدراسة إلى أن النمو الاقتصادي على المدى القصير يولد مزيداً من التدهور البيئي ولكن على المدى

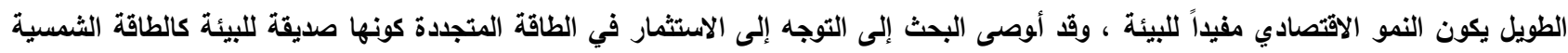

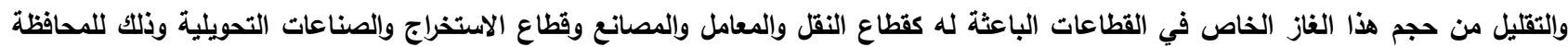

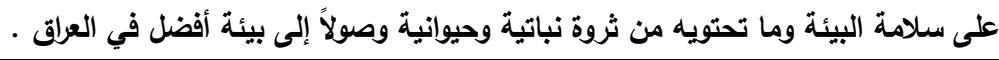

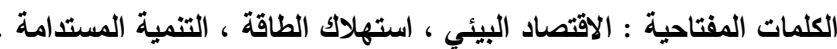

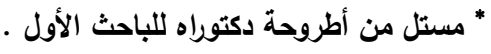




\section{INTRODUCTION}

Risks of global warming as a result of the expected rise in temperatures from one degree to 3.5 degrees celsius are the occurrence of changes in agricultural areas such as the decline of agricultural areas and sea level rise, which threatens to flood coastal agricultural lands and changes in the distribution of rain, which leads to the spread of desertification, the carbon dioxide $\mathrm{Co} 2$ is one of the biggest causes of degradation of the natural environment and the resulting of economic damages on the average per capita gross domestic product (9). One of the main sources of $\mathrm{Co} 2$ is the combustion of coal in thermal power plants and paper production plants in addition to the decomposition of organic matter and fertilizers, $\mathrm{Co} 2$ is one of the natural components of the atmosphere, and this gas contributes to influencing global warming. The current policies of countries and international authorities work to reduce levels of carbon dioxide (12). Pollution is the human activities that necessarily lead to the addition of a new materials or energy to the environment, as this energy endangers human life, health , livelihood or well-being to danger(1). The development of agricultural production in general and the development of human food in particular is a major concern for agricultural economic policy planners, especially in developing countries (6). In 1954, the economist (Simon Kuznets) gave a lecture entitled (Economic Growth and Income Inequality), which expressed various influences from environmental degradation and pollution, but with other levels of increased income will lead to environmental improvement (3) ; (11). Simon Kuznets believed that the distribution of income will be uneven in the early stages of growth, but this distribution moves towards equality with the continuation of economic growth. In the early stages of economic growth, both the average per capita income and environmental pollution move in the same direction and rise and assume growth in the Iraqi economy, especially agricultural economics entails high rates of environmental pollution and that the Kuznets curve applies to Iraqi economy. There are some hypothesis that are consistent with the Kuznets ecological curve (5). The research problem is summarized in the effect of $\mathrm{Co} 2$ gas emissions on economic growth and economic development and its impact on living organisms and thus its effect on increasing environmental degradation, high costs and declining levels of environmental sustainability. The research aims to estimate the most important factors affecting $\mathrm{Co} 2$ gas emissions for the period 2000-2017 in Iraq.

\section{MATERIALS AND METHODS}

This study relies on extracting its results on descriptive analysis as well as the use of methods of economic and econometric analysis of time series data spanning 18 years using the double logarithmic model, which is one of the best mathematical models. In such cases, the OLS was estimated using the Eviews10 statistical program.

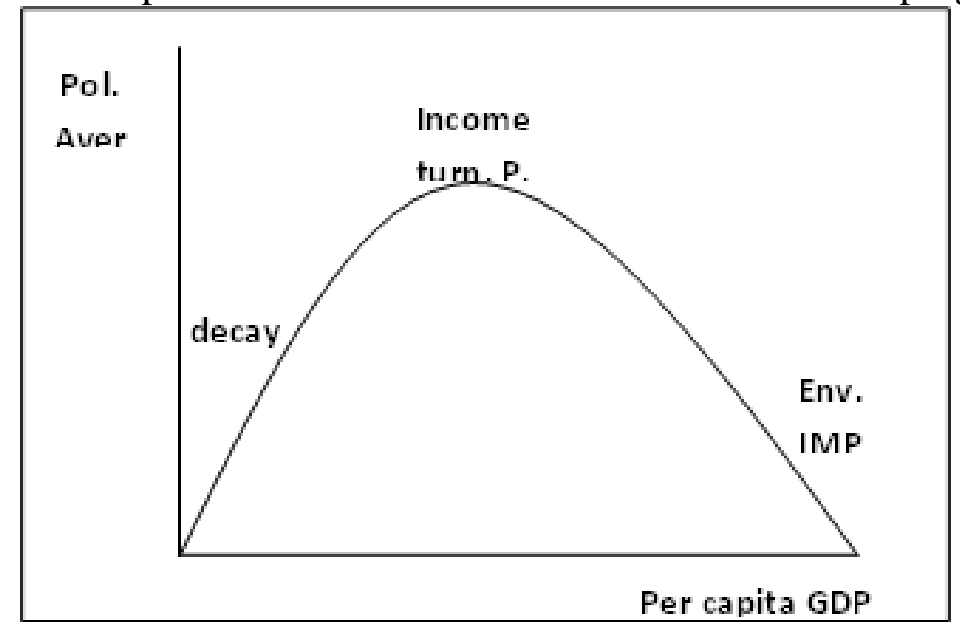

Fig. 1 Environmental Kuznets curve

Figure 1. Environmental Kuznets curve 
Through figure 1 its when the economy is small and the activities are simple and modest the pollution is in significant but with increase inactivities and the growth of the economy pollution is also growing and is increasing but with the movement of individuals towards the areas of improving the environment, the curve is down to the other again(4).

\section{RESULTS AND DISCUSSION}

Econometrics is a major tool that contributes to assessing the components of economic theory by giving numerical estimates that bring it closer to reality to be more logical and acceptable to obtain quantitative estimates that can be used in economic decision-making, forecasting and studying structural changes (14). Before we conduct econometric analysis, an analysis must be conducted economically, it was found from table 1 . that the average $\mathrm{CO} 2$ gas emissions in Iraq during the study period was 3.704 metric tons with a standard deviation of 0.655 , and average per capita energy consumption reached $1.249 \mathrm{~kg}$ of oil equivalent with a standard deviation of 286, As for the average per capita real GDP, It was \$ 3760.78 and its standard deviation is 1158.12 , and the average population density has reached 31003500 person with a standard deviation of 6553410 . The model also includes some of the controlling variables. Population density will be a positive relationship with the emission of carbon dioxide Co2. Also, a state that have external relations and allows free trade will have a higher probability of suffering from pollution levels than in a country that does not open its borders to free trade (13). Therefore it is expected that a trade openness (OPEN) as a dummy variable, will be positive or direct relationship with environmental degradation, may be due to increased economic activities such as mining rather than importing energy-saving technology (2). The OPEN variable was excluded from the analysis because it was not significant and did not affect the results of the analysis.

Table 1. Basic indicators for the data of the selected variables in Iraq for the period 2000-2017

\begin{tabular}{|cccccc|}
\hline & Co $_{2}$ & CONS & GDP & GDPSQ & Popul \\
\hline Mean & $\mathbf{3 . 7 0 4 6 1 5}$ & $\mathbf{1 . 2 4 9 0 1 4}$ & $\mathbf{3 7 6 0 . 7 8 0}$ & $\mathbf{1 5 4 3 3 1 3 0}$ & $\mathbf{3 1 0 0 3 5 0 0}$ \\
Median & $\mathbf{3 . 5 1 5 0 0 0}$ & $\mathbf{1 . 2 0 8 1 2 0}$ & $\mathbf{4 1 2 1 . 0 0 0}$ & $\mathbf{1 6 9 8 3 1 5 6}$ & $\mathbf{3 2 5 1 0 0 0}$ \\
Maximum & $\mathbf{5 . 0 6 0 0 0 0}$ & $\mathbf{1 . 8 6 0 0 4 0}$ & $\mathbf{5 3 3 8 . 5 2 0}$ & $\mathbf{2 8 4 9 9 7 9 6}$ & $\mathbf{3 7 2 0 4 0 0 0}$ \\
Minimum & $\mathbf{2 . 6 4 0 0 0 0}$ & $\mathbf{0 . 8 8 9 2 6 0}$ & $\mathbf{1 4 2 7 . 9 2 0}$ & $\mathbf{2 0 3 8 9 5 6}$ & $\mathbf{2 4 0 3 6 0 0 0}$ \\
Std.Dev & $\mathbf{0 . 6 5 5 8 7 3}$ & $\mathbf{0 . 2 8 6 3 7 9}$ & $\mathbf{1 1 5 8 . 1 2 4}$ & $\mathbf{8 2 0 6 9 4 9}$ & $\mathbf{6 5 5 3 4 1 0}$ \\
Skewness & $\mathbf{0 . 7 9 1 1 8 9}$ & $\mathbf{0 . 5 5 7 8 1 3}$ & $\mathbf{- 0 . 4 4 4 9 4 6}$ & $\mathbf{- 0 . 0 7 6 6 3 4}$ & $\mathbf{0 . 8 1 3 3 9 2}$ \\
Kurtosis & $\mathbf{2 . 6 7 7 1 8 6}$ & $\mathbf{2 . 2 8 3 4 3 3}$ & $\mathbf{1 . 9 6 5 1 2 6}$ & $\mathbf{1 . 8 2 3 6 3 8}$ & $\mathbf{2 . 0 8 1 2 4 0}$ \\
Jarque-bera & $\mathbf{2 . 8 2 5 4 7 0}$ & $\mathbf{1 . 9 0 4 5 9 8}$ & $\mathbf{2 . 0 1 8 1 1 0}$ & $\mathbf{1 . 5 2 4 5 9 6}$ & $\mathbf{1 . 9 3 5 8 5 1}$ \\
Probability & $\mathbf{0 . 2 4 3 4 7 6}$ & $\mathbf{0 . 3 8 5 8 5 3}$ & $\mathbf{0 . 3 6 4 5 6 3}$ & $\mathbf{0 . 4 6 6 5 9 3}$ & $\mathbf{0 . 2 2 1 5 6 7}$ \\
Sum & $\mathbf{9 6 . 3 2 0 0 0}$ & $\mathbf{3 2 . 4 7 4 3 7}$ & $\mathbf{9 7 7 8 0 . 2 8}$ & $\mathbf{4 . 0 1 E + 0 8}$ & $\mathbf{3 . 1 1 5 8 7 0}$ \\
Sum.sq & $\mathbf{1 0 . 7 5 4 2 5}$ & $\mathbf{2 . 0 5 0 3 2 7}$ & $\mathbf{3 3 5 3 1 2 5 8}$ & $\mathbf{1 . 6 8 e + 1 5}$ & $\mathbf{1 . 6 7 6 3 4 6}$ \\
Observations & $\mathbf{1 8}$ & $\mathbf{1 8}$ & $\mathbf{1 8}$ & $\mathbf{1 8}$ & $\mathbf{1 8}$ \\
\hline
\end{tabular}

Source: Researchers work by using Eviews 10. cannot reject the null hypothesis that each of It is evident from table 1 that the per capita share of energy consumption CONS and $\mathrm{CO} 2$ emissions have a positive skewness to the right, whereas the average per capita GDP and GDPSQ have a negative skewness to the left. Statistical results indicate that all of the researched variables have a kurtosis distribution curve, and all kurtosis coefficients are less than 3, which indicate that there is no concentration in one of the values at the expense of the other values. The Jarque-Bera test showed that the residuals of the variables are naturally distributed, where the probability value exceeds P-Value \% 5, and therefore we the variables discussed is distributed naturally. CORRELATION ANALYSIS: The coefficients matrix shows the correlation between the variables. Table 2 indicates that some variables are positively related and others negatively. Where the highest correlation between the variables was 0.783358 between $\mathrm{Co} 2$ gas emissions and population density, while the lowest correlation was between the average per capita energy consumption CONS and the population density of 0.024189 . 
Table 2 . Correlation Coefficient Matrix

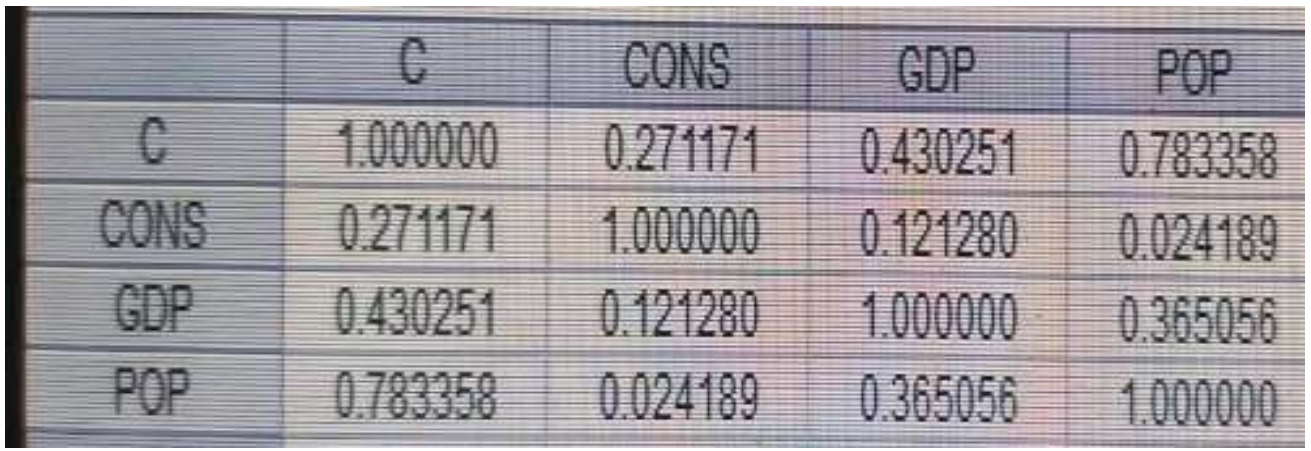

Source: Researchers work using Eviews 10

Our methodology is based on a single equation with several variables. Within this methodology, the Environmental Curve Kuznets ECK quadratic equation formula was used to study the relationship between $\mathrm{CO} 2$ emissions, and :average per capita GDP, square per capita GDP, CONS energy consumption, and POP population. This equation takes the following formula:

\section{$\mathrm{Co}_{2} \mathrm{t}$ $b_{2} G D P^{2}+b_{3} C O N S t+b_{4} P O P t+u t$}

Where $t$ stands for time, b's are parameter of the model, ut is error term.

Whereas:

Co2: Carbon dioxide emissions

b1 GDP: Real per capita GDP

b2 $\mathrm{GDP}^{2}$ : square per capita of real GDP

b3 CONS: Per capita energy consumption in kilograms of oil equivalent

b4 POP: Population density / million

b1: Is expected to be positive

b2: Expected to be negative based on the Kuznets hypothesis

b3: It is expected to be positive, because an increase in economic activity leads to an increase in energy consumption which in turn leads to an increase in $\mathrm{Co} 2$ emissions (8). b4: Expected to be positive, with population density, increasing co2 emissions

It should be noted that the model data were converted to logarithms before performing the econometric analysis on them in order to exclude the effect of significant differences in the amount and interpretation of the factors estimated as the elasticities for the dependent variable $\mathrm{CO} 2$ for each of the explanatory variables, and more importantly, this logarithmic transformation reduces the problem of variation difference or Heteroscidasticity (10). The econometric model was estimated with a Log-Log dual model, which is considered the best mathematical model in such an analysis. The relationship was expressed with the following equations:

$\mathrm{Lny}_{\mathrm{t}}=\mathrm{B}_{0}+\mathrm{LnB}_{1}+\mathrm{LnB}_{2} \mathrm{X}^{2}+\mathrm{ut}$

$\operatorname{LnEC} C_{\mathrm{t}}=\mathrm{B}_{0}+\mathrm{B}_{1} \operatorname{Ln}\left(\mathrm{GDP}_{\mathrm{pc}}\right)+\mathrm{B}_{2} \operatorname{Ln}\left(\mathrm{GDP}^{2}{ }_{\mathrm{Pc}}\right)+$ $\mathrm{B}_{3} \operatorname{Ln}\left(\mathrm{CONS}_{\mathrm{Pc}}\right)+\mathrm{B}_{4} \operatorname{Ln}\left(\mathrm{POP}_{\mathrm{Pc}}\right)+\mathrm{ut}$

Before the analysis, a time series stability process was performed to ensure that the data is free from the unit root problem and after testing it was found that all data is static and that the regression results are not spurious and are reliable.

Table 3. Results of the econometric, analysis 


\section{Dependent Variable: $\mathrm{LOG}(\mathrm{CO} 2)$ \\ Method: Least Squares \\ Date: 03/29/20 Time: 20.45 \\ Sample: 20002017 \\ Included observations: 18

\begin{tabular}{crrrr}
\hline \hline Variable & Coefficient & Std. Error & t-Statistic & Prob. \\
\hline \hline C & 9.680014 & 0.069980 & 138.3254 & 0.0000 \\
LOG(GDP) & 0.467551 & 0.005282 & 88.5177 & 0.0000 \\
LOG(GDPSQ) & -0.036022 & 0.007760 & -4.642010 & 0.0017 \\
LOG(CONS) & -0.041359 & 0.002367 & -17.47317 & 0.0020 \\
LOG(POP) & 8.111815 & 0.0933174 & 86.927143 & 0.0000 \\
\hline \hline R-squared & 0.992435 & Mean dependentvar & 13.123187 \\
Adjusted R-squared & 0.987130 & S.D. dependentvar & 0.041128 \\
S.E. of regression & 0.097005 & Sum squared resid & 0.001614 \\
F-statistic & 428.8280 & Durbin-Watson stat & 1.680335
\end{tabular}

Source: Researcher's work based on Eviews 10 program.

Statistically, the explanatory variables were all significant at the level of $1 \%$ and the model was significant at the same level as the value of $\mathrm{F}$ is approximately 429 and this confirms the reality of the function on the one hand and to the importance of the explanatory variables used in the model on the other hand, Also the explanatory variables were able to explain $99 \%$ of variations in the dependent variable $\mathrm{Co} 2$, which they are :average per capita gross domestic product (GDP), square average per capita GDP (GDPSQ), per capita energy consumption (CONS), and population density (POP), and only $1 \%$ of the residuals was not explained and was due to random errors. For the economic side, we find that the intercept $\mathrm{C}$ reached 9.680 and it was significant, while the GDP parameter reached 0.467 and it has positive sign came in line with the economic logic and with the environmental Kuznets methodology, which means increasing the average per capita GDP by one percent, then the $\mathrm{CO} 2$ emissions will increase by $0.46 \%$, and the GDPSQ parameter was 0.036 and it came with a negative signal and it is consistent with Kuznets' environmental methodology which assumed the negative signal and which
Kuznets suggested was a slowdown and it refer to an inequality in economic growth that $t$ reflects on the square of the average per capita gross domestic product, but as for the CONS parameter it reached 0.041 and it came with a negative signal also and this contradicts the Kuznets approach and the reason may be due to the study period, especially after 2003 and the conditions that surrounded the country led to a decrease in economic activity, which was reflected on a decrease in energy consumption in the production, which in turn led to a clear decrease in $\mathrm{Co} 2$ emissions, knowing that it is related to emissions of economic activity for energy consumption and not emissions from car exhausts. As for the parameter of the population, it reached 8.111 and it came with a positive sign consistent with the economic and environmental approach and that mean increasing the population density by one percent will increase $\mathrm{CO} 2$ emissions by $8.11 \%$. As for the econometric tests or econometric problems, they were revealed through the estimated model that the value of $\mathrm{D}-\mathrm{W}$ was 1.680 , and this suggests that the model suffers from a positive Auto-correlation problem and through a double test of LMRA to ensure that the problem exists in the model 
through the Eviews10 program and in two lagged time it turns out that and the value of It has reached 0.3758 which is greater than (0.05), and this is evidence that the model does not suffer from the problem of Autocorrelation and therefore we do not reject the null hypothesis (we accept it) that there is no Autocorrelation problem. For the problem of Heteroscidasticity, although this problem appears clearly in the cross section data than in time series, however, we conducted a test to detect the problem or not, and through the Pagan- Godfrey test, which is a test based on the dynamics of squared residues and makes a regression for them on the independent variables and it depends on the value of $F$ which reached 1.2243 and was not significant and therefore we do not reject the null hypothesis and the model is good and does not have the problem of Heteroscidasticity. As long as the model is double logarithmic, i.e. non-linear, then such a model satisfies the assumption that there is no multiple linear relationship between the explanatory variables or Multicollinearity, since the model is nonlinear in the variables (7).

Table 4. The Kuznets environmental curve hypothesis test

\begin{tabular}{|c|c|c|c|c|}
\hline Parameter & b1 & b2 & b3 & b4 \\
\hline Theory & $\begin{array}{l}\text { There is a positive } \\
\text { relationship between } \\
\text { average per capita } \\
\text { gross domestic } \\
\text { product and carbon } \\
\text { dioxide emissions. }\end{array}$ & $\begin{array}{l}\text { There is an inverse } \\
\text { relationship between } \\
\text { the square values of } \\
\text { average per capita } \\
\text { gross domestic } \\
\text { product and carbon } \\
\text { dioxide emissions. }\end{array}$ & \begin{tabular}{lr} 
There is a positive \\
relationship \\
between average per \\
capitarass \\
domestic product \\
and carbon dioxide \\
\multicolumn{2}{r}{ emissions. }
\end{tabular} & $\begin{array}{l}\text { There is a direct } \\
\text { relationship } \\
\text { between } \\
\text { population density } \\
\text { and carbon } \\
\text { dioxide emissions }\end{array}$ \\
\hline $\begin{array}{c}\text { Expected } \\
\text { Values }\end{array}$ & Positive & Negative & Positive & Positive \\
\hline $\begin{array}{l}\text { Actual } \\
\text { Values }\end{array}$ & Positive & Negative & Negative & Positive \\
\hline
\end{tabular}

Source: Researchers work based on the results of the analysis in Eviews10

The research concluded that the effect of the average per capita gross domestic product had a direct positive effect in increasing $\mathrm{Co} 2$ gas emissions, however, due to the decrease in the productive and economic activity of the country during the study period, the effect of the per capita energy consumption CONS was negative on $\mathrm{Co} 2$ gas emissions, which was supposed to its relationship is direct with the emissions of this gas according to the Kuznets methodology The population density has a direct relationship with $\mathrm{Co} 2$ gas emissions. The hypothesis has been proven that the $\mathrm{Co} 2$ emissions in Iraq are subject to the Kuznets curve, and the research recommended investing in renewable energy and using it as sunlight, water and wind power and trying to reduce the volume of gas emissions, especially in the transportation and manufacturing sectors, which will play a role in reducing high temperatures, as well as the research recommended to include the environmental standards in economic analysis effectively for the current assurances in policy making and analysis on economic growth and environmentally sound and sustainable economic development. It is also preferable to test the Kuznets curve as a non-linear relationship and try to extract the critical income size that the country must reach for the relationship between income and pollution to become negative or reverse.

\section{REFERENCES}

1. Abboud , S.M. 2015. Sustainable development and environmental costs. Doctor publishing for administrative and economic sciences . first edition, Baghdad , p.p. 23-24

2. Akin, C.S. 2014. The Impact of Foreign Trades Energy Consumption and Income on $\mathrm{Co}_{2}$ Emissions International Journal of Energy Economics and Policy . 4(3) , 465-475

3. Alaga, A.T. 2008. Economic growth and its Impact on the Environmental Sustainability of Developing Countries. Al-Zaytoonah University Conference. Jordan: p.p.5

4. Alan, G., et.al. 1997 , Applied Economics , Sever Edition London : Longman limited, p.p. 23

5. Alwan, Q. et.al. 2017 . The mutual effects between economic growth and carbon dioxide emmissions within the hypothesis of the environmental kuznets curve, Jordan case 
study, Jordanian journal of Economic sciences . 1(2), p.p.90 .

6. Barbaz, D.S, and et.al . 2020. Estimation of profit function wheat Crop in Dhiqar Province. The Iraqi Journal of agricultural sciences (51) Special Issue: $238-244$

7. Gujarati, N.D. 2004. Basic Econometrics. Mc - Grow Hill Co. Press LTD: p.p 405

8. Jayanthah, U.M. 2012. $\mathrm{Co}_{2}$ Emission, Energy Consumption Trade and Income: A Comparative Analysis of China and India Energy Policy : 450-460

9. Latifa, L. 2019. A Standard Study of The Effect of $\mathrm{Co}_{2}$, Gas Emission on Algeria GDP for Period 1980-2014. Scientific Afaq Magazine. 11(3): 766

10. Maddala, 1. M. 1998. Unit Root, Cointegration and Structural Change Themes in Modern Econometrics. Cambridge University Press : p.p 210
11. Markandya, P. H. 2002. Environmental Economics for Sustainable Growth. USA: p.p 23

12. Nasr, A.R. 2010. The Effect of Climate Properties on Occurrence of Global Warming. Babylon University Journal 8(1):5

13. Sharma, MS. 2011. Determinates of Carbon dioxide is a Emissions : Imperial Evidence from 69 Countries Applied Energy, p.p 88

14. Shukur, A.S. 2015. An economic analysis of cost and profit efficient and technical efficiency of tomato crop in Diyala governorate. the Iraqi journal of agricultural science. 46(5): 76-82

15. Yandle, B., et. al. 2002. The Environmental Kuznets Curve. A Prime PERC Research study, p.p. 10. 